\title{
The critical condition of hutias in Cuba
}

\author{
Vicente Berovides Alvarez and Antonio Comas González
}

Cuba is home for 10 endemic species of hutia. Three of these have become scarce, or extinct, in some parts of their historical range, but remain sufficiently abundant elsewhere to make their conservation of no immediate concern. Of the other seven species, one is believed to be extinct and the rest are in grave danger. The pressures they face include capture by man, competition with introduced rats and destuction of their habitat. Urgent measures are required if these species are to survive.

Hutias belong to the Capromyinae, a subfamily of rodents that occurs only in the West Indies-in Jamaica, on Little Swan Island off north-eastern Honduras, in the Bahamas and in Cuba. While Jamaica and Little Swan Island share one species and the Bahamas has another, single species, Cuba has 10 extant species (Varona, 1974, 1979, 1986). Kratochvil et al. (1978) divide the subfamily into three genera and this classification is used here.

In terms of abundance, the hutias of Cuba fall into two groups. The first comprises Capromys pilorides, Mysateles prehensilis, and $M$. melanurus. All three are locally abundant in some places, but very scarce or extinct in others. C. pilorides is so numerous in some locations that it causes a great deal of damage to the vegetation. In some protected areas its density has reached 50 individuals per ha and some mangrove swamps contain up to 100 individuals per ha. In other locations, especially in the mountains of eastern Cuba, the population of $C$. pilorides has been reduced enormously. Similarly, M. prehensilis is sufficiently numerous in parts of its range to cause great damage to plantations, and $M$. melanurus is abundant in some parts of its eastern range but very scarce in the northern part.

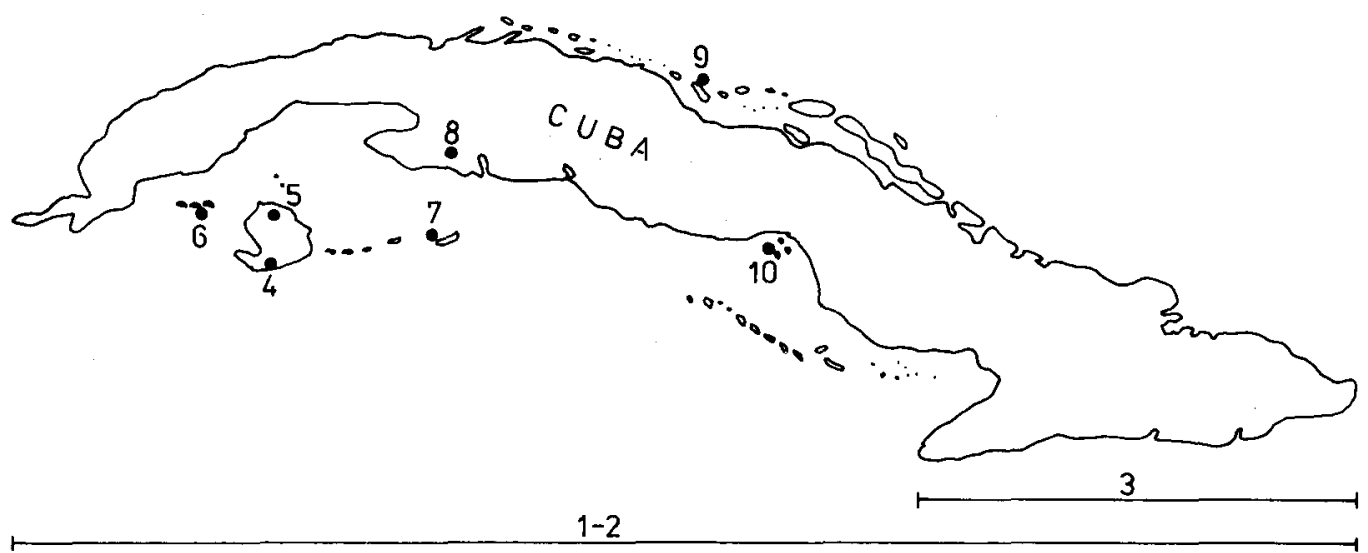

Figure 1. Map showing the distribution of hutia species in Cuba. 1. Capromys pilorides (throughout Cuba); 2. Mysateles prehensilis (throughout Cuba); 3. Mysateles melanurus (eastern region); 4. Mysateles meridionalis (southern island of Juventud); 5. Mysateles gundlachi (northern island of Juventud); 6. Mesocapromys sanfelipensis (Juan García Key); 7. Mesocapromys garridooi (Majaés and Cayo Largo Keys); 8. Mesocapromys nana (Zapata swamp); 9. Mesocapromys auritus (Fragoso Key); 10 Mesocapromys angelcabrerai (Ana Maria Keys). 
These three species are not of immediate conservation concern. If necessary they could be reintroduced into the places where they have disappeared, using captured animals from similar habitats with high densities.

The second group consists of Mesocapromys sanfelipensis, $M$. garridoi, $M$. nana, $M$. auritus, $M$. angelcabrerai, Mysateles gundlachi and $M$. meridionalis. One of these is believed to be already extinct and the rest are all in grave danger. The members of the genus Mesocapromys are small, form colonies of many individuals and are restricted to marginal areas, principally to islands off Cuba and to swamps in Cuba itself.

\section{Mesocapromys sanfelipensis}

It appears that this species, which was reported as a new species in 1970 (Varona and Garrido, 1970) has been extirpated from its only recorded location-Juan García Key, on San Felipe Keys. Frías et al. (1988) suggested that the causes of its decline and subsequent disappearance are threefold. From the time of its discovery it has been subject to capture by humans and competition with introduced rats Rattus rattus, which migrated to the mangrove and salt marsh habitats of the hutia after the human dwellings on Juan García Key were abandoned. These impacts must have had a serious effect, because, like other Capromyids, the species is is long-lived and has a low fecundity (Clought, 1972). In addition, Juan García Key is only 137.5 ha and competition with rats must have been intense. The final blow for this hutia was probably habitat destruction, first by fires lit by fishermen to drive off mosqitoes and then by a huge increase in human activity in 1988-89, which left virtually no suitable habitat.

\section{M. auritus}

This is also localized and occurs in reduced numbers in the centre of the Fragoso Key. Because its effective population is small the prospects for its survival are uncertain and also dependent upon future development of the area it occupies.

\section{M. garridoi}

This species was believed extinct until, in 1989, two individuals were captured alive in keys adjacent to their previously known distribution. It must be scarce, however, and human activity in its range is increasing.

\section{M. nana}

This hutia has not been sighted since 1930 but is believed to survive still because its tracks and faeces have been seen recently.

\section{M. angelcabrerai}

This species is very localized but is abundant in the areas of red mangrove forest where it occurs; the area is remote and there are no plans for development.

\section{Mysateles meridionalis and $\boldsymbol{M}$. gundlachi.}

These two species are extremely vulnerable to capture by humans and to the introduction of exotic animals. These forest-dwelling species live on the island of Juventud and have been recognized as new species only recently. $M$. meridionalis, which lives in the southern part of the island, was described only after collecting five individuals over a 10 -year period. The second species, $M$. gundlachi, which lives in the northern part of the island, has been severely affected by forest destruction.

\section{Conservation}

There is now a move to protect Cuba's hutias, but it is clear that major efforts are necessary if the story of the extermination of $M$. sanfelipensis is not to be repeated for the 


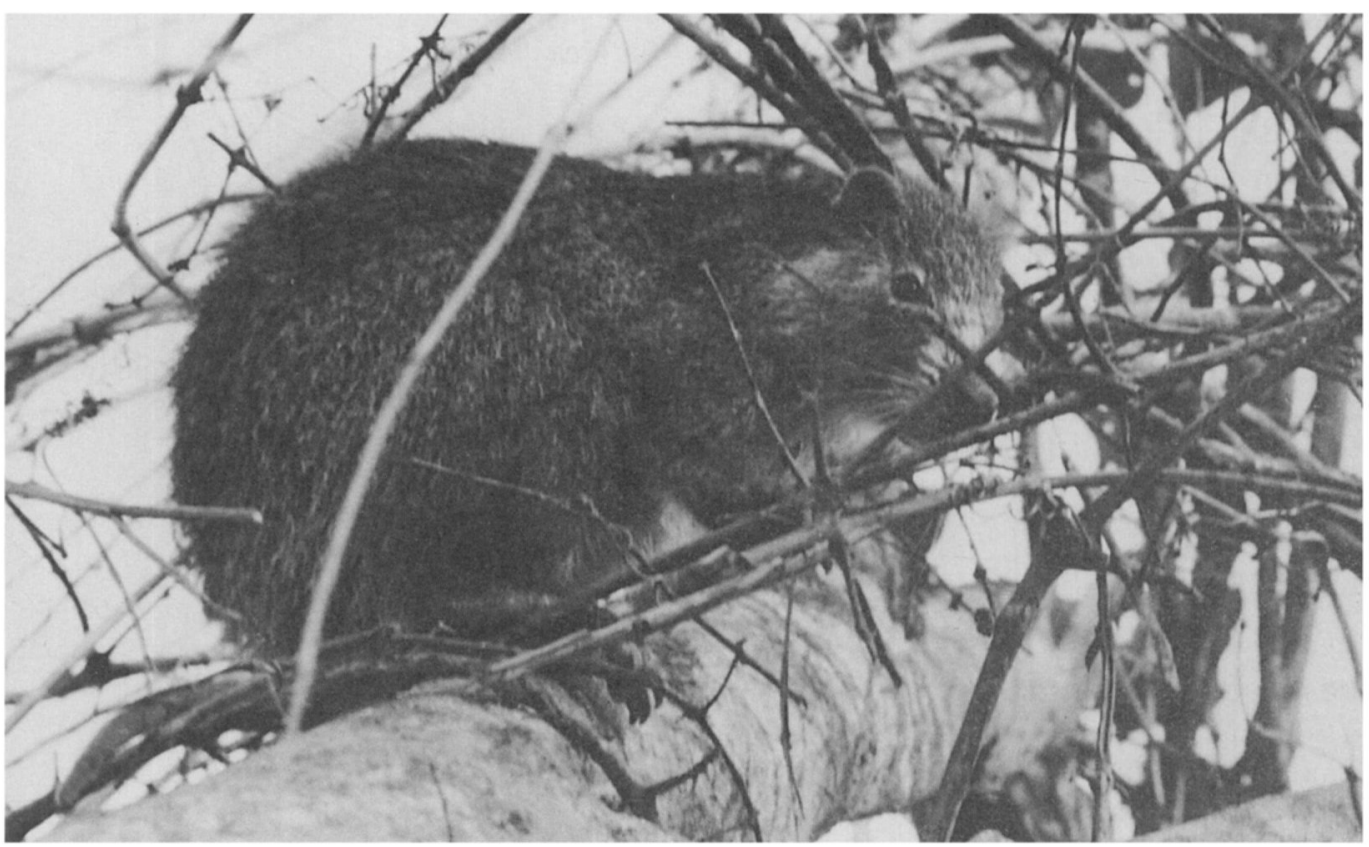

Capromys pilorides, the most abundant species of hutia in Cuba (V. Berovides Alvarez).

other species. As a minimum the following measures are urgently needed:

1. protecting the locations of the species in question;

2. surveying and monitoring the population of each species;

3. captive breeding as a means of providing individuals for reintroduction into previously occupied habitat. This last measure has produced good results with the Jamaican hutia Geocapromys brownii (Oliver et al.,1986)

With these measures we are confident that we can ensure the survival of Cuba's endemic hutias.

\section{References}

Clought, G.C. 1972. Biology of the Bahamian hutia Geocapromys ingrahami. J Mammal. 53, 807-823.

Frías, A.J., Berovides, V. and Fernández, C. 1988. Situación actual de la jutiita de la tierra Capromys sanfelipensis (Rodentia, Mammalia). Doñana Acta Vert. 15, 252-254.
Kratochvil, J.L., Rodriguez, L. and Barus, V. 1978. Capromyinae (Rodentia) of Cuba (I). Acta Sci. Nat. Brno. 12 (11), 1-60.

Oliver, W.L.R., Wilkins, L., Kerr, R.H. and Kelly, D. 1986. The Jamaican hutia Geocapromys brownii; captive breeding and reintroduction programme-history and progress. Dodo, 23, 32-58.

Varona, L.S. 1974. Catálogo de los Mamiferos Vivientes y Extinguidos de Las Antillas. Acad. Ciencias Cuba, La Habana, 140pp.

Varona, L.S. 1979. Subgénero y especie nuevos de Capromys (Rodentia: Caviomorpha) para Cuba. Poeyana, 194, 1-33.

Varona, L.S. 1986. Taxones del subgénero Mysateles en isla de la Juventud, Cuba. Descripción de una nueva especie. Poeyana, 315, 1-12.

Varona, L.S. and Garrido, O.H. 1970. Vertebrados de los Cayos de San Felipe, incluyendo una neuva especie de jutia. Poeyana. A. 75, 1-26.

Vicente Berovides Alvarez, Biology Faculty, No. 455, Calle 25, Vedado, Havana 4, Cuba.

Antonio Comas González, Instituto de Investigaciones Forestales, Ministerio de la Agricultura, Cuba. 